\title{
Correlation between the rainfall, sediment recharge, and triggering of torrential flows in the Rebaixader catchment (Pyrenees, Spain)
}

\author{
Roberta Pastorello, $1 \square$ \\ Phone: 00390498272700 \\ Email: roberta.pastorello@studenti.unipd.it \\ Marcel Hürlimann, 2 \\ Email: marcel.hurlimann@upc.edu
}

Vincenzo D'Agostino,

Email: vincenzo.dagostino@unipd.it

1 Department of Land, Environment, Agriculture and Forestry (TeSAF), University of Padova, 35020 Legnaro, Italy

2 Division of Geotechnical Engineering and Geosciences, Department of Civil and Environmental Engineering, BarcelonaTech (UPC), 08034 Barcelona, Spain

Received: 9 August 2017 / Accepted: 27 April 2018

\begin{abstract}
The debris flow (DF) and debris flood (DFD) activity in the Rebaixader catchment (Spanish Pyrenees) is analyzed in this study. The research is focused on how precipitation leads to the triggering of torrential floods and influences the sediment availability during the recharge period, in a supplyunlimited catchment. Two kinds of correlations are studied: (1) the correlation between the rainfall features (intensity and kinetic energy) and the DF/DFD triggering and (2) the correlation between the hyetograph and the DF/DFD volumes. The tested hypothesis was that a greater amount of rainfall during the recharge period would produce a greater DF/DFD volume. The period
\end{abstract}


between two consecutive DF/DFD events is processed using a variable, the Erosion Index, originally developed for the Universal Soil Loss Equation. This analysis considered the rainfall time series and 22 DF/DFD events registered during the period 2009-2015. The results show that the precipitation of the recharge period does not seem to have a strong influence on the mobilized volumes. In many cases, a second DF/DFD event was triggered soon after the previous event, which highlighted the role of the first event in creating an unstable state of the catchment. Additionally, a threshold relationship between the kinetic energy of the rainfall event and the maximum rainfall intensity for a $30-\mathrm{min}$ period seems to be a good criterion to discriminate between triggering and non-triggering rainfall events. The results show no clear trends with which to forecast the sediment volume from precipitation, weakening the role of rainfall characteristics in determining the return period of mobilized sediment volumes in catchments similar to the Rebaixader torrent.

\section{Keywords}

Debris flow

Debris flood

Rainfall

Erosion index

Pyrenees

Recharge period

\section{Electronic supplementary material}

The online version of this article ( https://doi.org/10.1007/s10346-018-1000-6 ) contains supplementary material, which is available to authorized users.

\section{Introduction}

Torrential flows such as debris flow (DF) and debris flood (DFD) are natural phenomena that affect mountain areas all over the planet. Debris flows are very rapid to extremely rapid surging flows of saturated debris moving in steep channels. They are characterized by strong entrainment of material and water from the flow path (Hungr et al. 2013), whereas debris floods are very rapid flows of water, heavily charged with debris, in a steep channel, characterized by peak discharges comparable to those of water floods (Hungr et al. 2013).

Because of their characteristics, they are complicated events to forecast (Destro et al. 2017). They can occur with large magnitudes (Marchi and D'Agostino 
2004; Jacob Jakob 2005), and they consequently cause considerable damage to human lives and infrastructures (Dowling and Santi 2014). Many studies demonstrated the fundamental role of precipitation in the triggering of a DF/DFD event, the rate of the available sediment, and the total sediment volume delivered to the fan area (Deganutti et al. 2000; Bacchini and Zannoni 2003; Crosta and Frattini 2003, 2008; Borga et al. 2014; Abancó et al. 2016). A fundamental step to develop more efficient and reliable systems of prevention is to improve the understanding of the triggering mechanisms and to predict the mobilized volume and the recharge rate of sediments within the catchment. To this purpose, different catchments that are frequently subjected to DF/DFD events have been instrumented with meteorological stations and sensors. These sensors register the deposited volume and passed surges for a given cross section (Hürlimann et al. 2003; McArdell et al. 2007; Coe et al. 2008; Berger et al. 2011; Comiti et al. 2014; Bel et al. 2017).

$\mathrm{AQ} 2$

DF/DFD catchments can be divided into two different types: transport-limited (also named supply-unlimited) and weathering-limited (also named supplylimited). The transport-limited catchments are characterized by a high frequency of DF/DFD events, but they usually have a low/moderate magnitude because of their frequent sediment release (Bovis and Jakob 1999; Jakob 2005). In these catchments, there is unlimited sediment availability, and so, a DF/DFD event can be triggered every time the rainfall exceeds a defined threshold (e.g., intensityduration, Guzzetti et al. 2008). The supply-unlimited basins usually have many erodible areas or "source areas" that are continuously prone to instability (D'Agostino and Bertoldi 2014). Therefore, other variables in addition to sediment availability (e.g., water input, terrain morphology, channel network characteristics, connectivity, see Cavalli et al. 2013) play an important role in triggering the events and in the transport and deposition of the available sediment.

AQ3

The second type of catchments, named supply-limited or weathering-limited, has a limited sediment availability, and so, a DF/DFD event is triggered by rainfall only if the sediment quantity in a source area (channel network included) has reached or exceeded a defined threshold of accumulation (e.g., 50 years of sediment recharge due to weathering and water-driven transport processes since the last DF/DFD occurrence). In supply-limited basins, the frequency of the $\mathrm{DF} / \mathrm{DFD}$ events is usually lower compared to that in supply-unlimited basins, but the magnitude of these events can be higher if the non-active periods are much longer. In these catchments, the time interval between two DF/DFD events is called the "recharge period." "recharge period". In fact, during this rest time, 
a catchment recharges itself with new loose debris. Often, after a DF/DFD event, source areas and channels have a smaller quantity of loose sediment that can be mobilized (Jakob 2005), so the recharge period is needed to accumulate new sediment (Theule et al. 2012). The length of this period depends on different factors, such as the presence of vegetation (Guthrie 2002), bedrock geology, meteorological characteristics, and the rate of erosional processes (Carrara et al. 2008; Dong et al. 2009). Conversely, Brayshaw and Hassan (2009) suggested that a substantial correlation of the timing and volume of a DF event with the following event might occur. In fact, in the period following a DF/DFD event, the catchment is more unstable and continues to promote the transportation of loose debris cover to the channel, which can facilitate the triggering of another event.

The probability of DF/DFD occurrence depends on the morphological characteristics of the basin and the recharge rate during the intermediate period between two consecutive events (Jakob et al. 2005; Corominas and Moya 2008). Moreover, in all types of basins, the key variable that leads to the triggering of a DF/DFD event is the surface runoff (Rickenmann and Zimmermann 1993; Berti and Simoni 2005; Gregoretti and Dalla Fontana 2008). This runoff is usually generated by intense rainfall events, and in fact, it has been demonstrated by many studies (Wieczorek and Glade 2005; Kappes et al. 2011, 2012; Reid et al. 2012; Cavalli et al. 2013) that the most common events causing debris flows are summer storms (Berti and Simoni 2005; McCoy et al. 2010; Di Stefano et al. 2013).

For definition, the concept of recharge period is related only to supply-limited basins (Bovis and Jakob 1999; Brayshaw and Hassan 2009). Nevertheless, in this study, we wanted to investigate if the same concept of recharge period can also be applied to supply-unlimited catchments. In supply-unlimited catchments, a recharge cycle may exist (like in supply-limited basins), but these cycles are very short compared to the ones observed in other types of catchments. In addition, even the triggering conditions of torrential flows in a supply-unlimited catchment could be influenced by the recharge period and not only by a constant triggering rainfall threshold. During a no-DF/DFD period (rest period), low/medium-intensity rainfalls could continue to erode sediment source areas, increasing the sediment availability in the basin according to the kinetic energy of precipitations.

To briefly summarize the previous statements, it can be concluded that possible correlations both between the DF/DFD volume and the duration of the recharge period and between the DF/DFD timing and the amount of rain accumulated during the recharge period are poorly investigated. Recently, Bel et al. (2017) 
tested similar correlations between extreme rainfalls and entrained DF volumes, but they did not find significant correlations. The linkage between the return period of the DF/DFD volume and the physical characteristics of both the preparatory and triggering precipitation-especially merits further investigation. The need for this knowledge is evidenced by the standard approach to hazard map preparation and to a design of protective structures against debris flows, since both tasks are very often based on the return period of the involved variables (e.g., critical rainfall intensities and subsequent transformation into runoff/sediment volumes).

In this study, we analyzed a small catchment named Rebaixader (Pyrenees, Spain) that has been equipped since the summer of 2009 with a monitoring system that records DF/DFD events and meteorological data (Hürlimann et al. 2014). In particular, we investigate if the triggering of torrential flows in a supply-unlimited catchment could be influenced by the recharge period and not only by a triggering rainfall threshold. We assume that rainfalls could produce erosion in the source area, increasing the available sediment, and so, we analyze the precipitations during the interval period between two torrential events. Therefore, our research considers the following questions:

1. If the volume of DF/DFD events depends on (1) the intermediate rainfall (recharge period), (2) the triggering rainfall, and/or (3) the total kinetic energy of the rainfall, similar to what Wischmeier and Smith (1978) have found in developing the Universal Soil Loss Equation (USLE).

2. If there are any thresholds related to different variables (i.e., rain erosivity/kinetic energy) that are better performing in the identification of the potential DF/DFD triggering than the classic rainfall intensity-duration thresholds. This could be a step forward from the traditional concept that the DF return period is related to the rainfall.

After the study area presentation, the "Materials and methods" section illustrates how the rain data and information on DF/DFD volumes are used in the research. Correlations between the selected variables are shown in the "Results" section. The discussion takes into consideration the results to fulfill the research considerations described above and to highlight the elements of novelty in this approach. The supplementary data section (Online Resource 1) presents the features of each DF/DFD event and supports the discussion and conclusion on the timing and agreement/disagreement between preparatory and generating precipitations and sediment volumes of the DF/DFD.

\section{Study area}


The catchment analyzed in this study is crossed by the Rebaixader torrent and represents a typical high mountain watershed. It is located in the Central Spanish Pyrenees, near the village of Senet, on the border between Catalonia and Aragon (Fig. 1).

\section{Fig. 1}

Map of the Rebaixader torrent catchment. a Orthophoto. b Slope map 


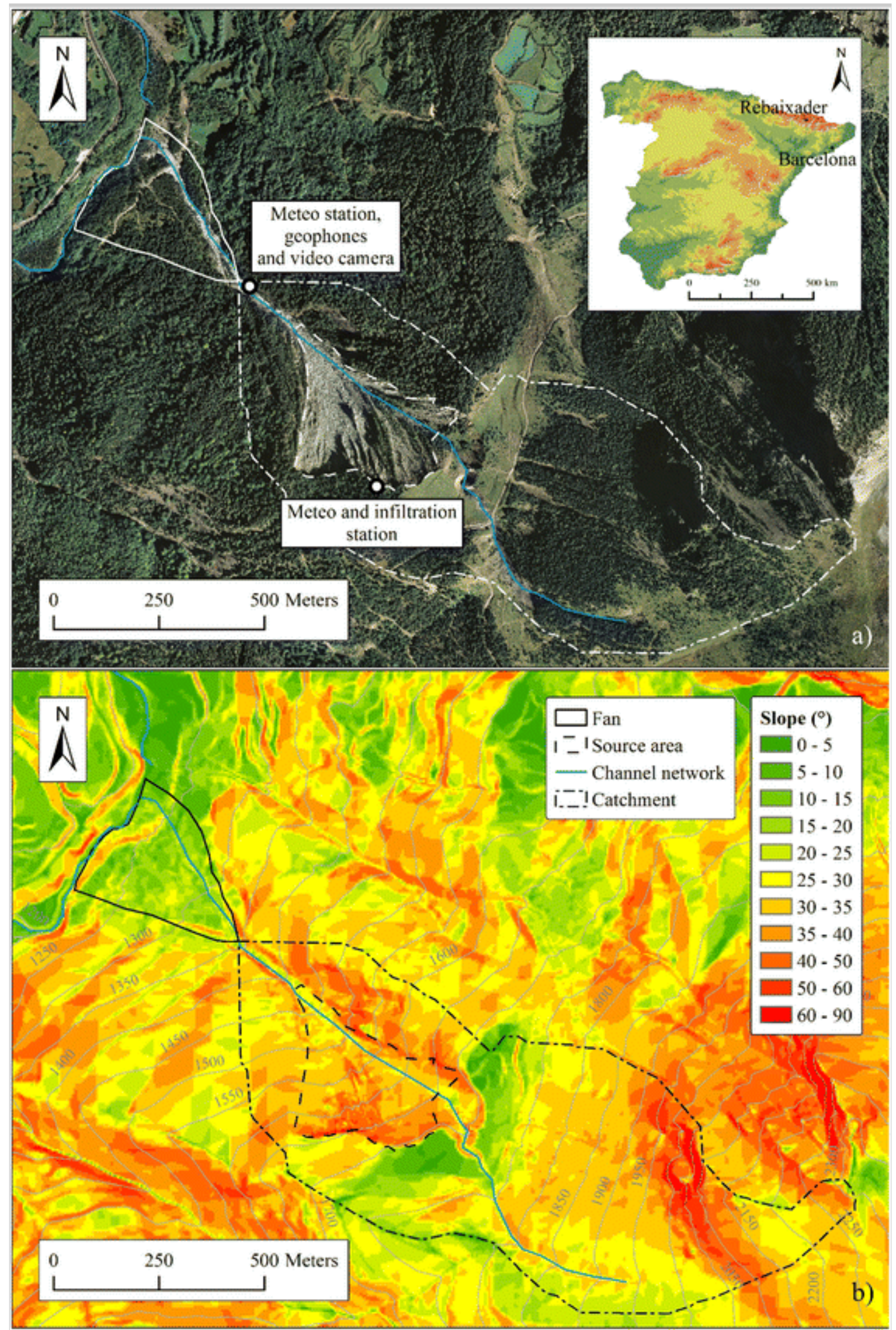

The catchment has a drainage area of $0.53 \mathrm{~km}^{2}$ and an elevation that ranges between a maximum of $2310 \mathrm{~m}$ a.s.1. and a minimum of $1775 \mathrm{~m}$ a.s.1., the latter corresponding with the fan apex. The bedrock of the catchment is Paleozoic metamorphic rocks and mostly consists of Devonian slates and phyllites formed during the Hercynian orogeny (Munoz 1992). Colluvium and granular glacial 
deposits cover the bedrock. The large lateral moraine located between 1425 and $1710 \mathrm{~m}$ a.s.l. strongly affects the morphologic characteristics of the drainage basin and incorporates the source area of the DF/DFD events.

The catchment can be divided into two main zones: the upper part is characterized by the presence of forest and grassland. It includes steep slopes in the highest area and a flat area at approximately $1710 \mathrm{~m}$ a.s.1., which is associated with the upper limit of the lateral moraine. This upper part makes no significant contribution to the creation and accumulation of sediment. The lower part of the catchment is characterized by the presence of a large area covered by the loose debris of the lateral moraine, which is the source area of the DF/DFD events. The source area is linked to the fan by a short transport channel (Fig. 1). Therefore, we can define this catchment as supply-unlimited, characterized by the presence of a unique, bare-soil area, which governs the DF/DFD phenomena according to sediment supply conditions, overall hillslope stability and rainfall aggressiveness.

The source area has an extent of approximately $0.09 \mathrm{~km}^{2}$, a mean slope angle of $35^{\circ}$ with a maximum value of $61^{\circ}$, and an altitudinal gradient that ranges from 1709 to $1400 \mathrm{~m}$ a.s.l. (the point where the transport channel originates). The loose sediment of the large lateral moraine that is frequently subjected to erosion characterizes this part of the catchment. These sediments range in size from sand/gravel to boulders with a diameter of several meters (for more details on the grain size distribution, see Hürlimann et al. 2012). An example of the morphology of the source area is shown in Fig. 2, where the particular erosive pattern of a "badland-like" zone is evident and presents sparse and vegetated "islands" of apparent stability. The steepness of the large source area and the availability of loose sediment have made the catchment very active, as confirmed by the occurrence of several DF and DFD events per year.

\section{Fig. 2}

A peculiar "badland-like" morphology located in the source area 


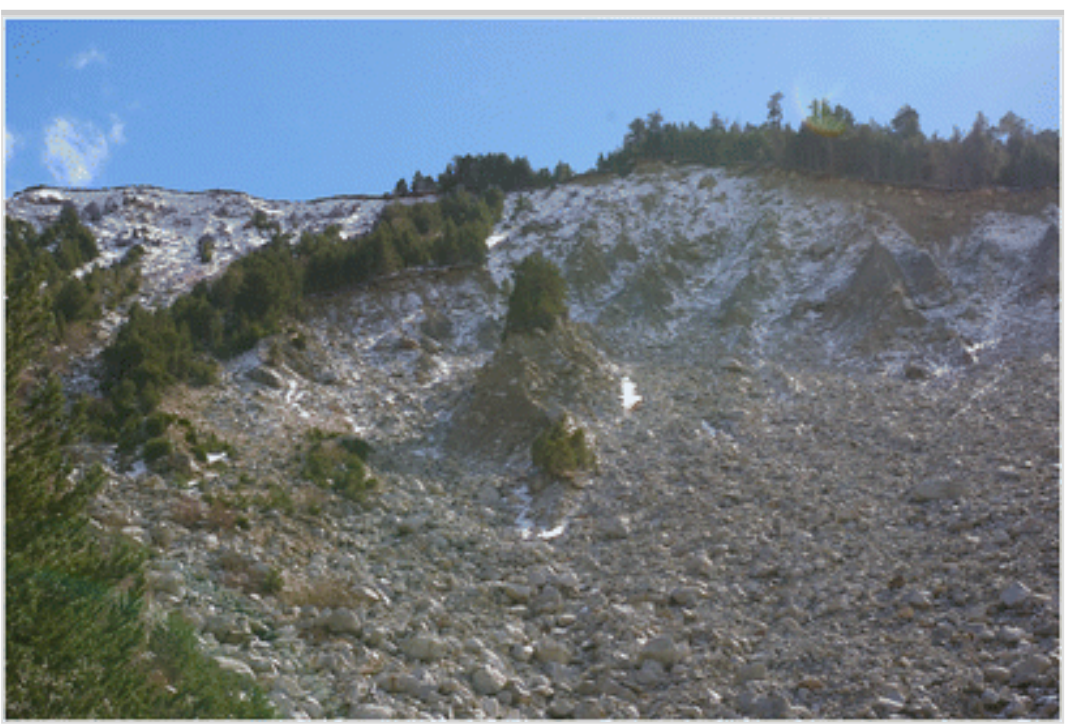

The transport channel is approximately $200 \mathrm{~m}$ long and has a width of approximately $10 \mathrm{~m}$. A fan forms the accumulation area of the catchment, and the Noguera Ribagorçana River bounds it.

An important characteristic of the Rebaixader basin is the fact that no control structures are installed to protect from torrential flows. Therefore, the behavior of the channel and of the source area is not influenced by the presence of check dams or similar structures. In the summer of 2009, a monitoring station system was installed in the source area and transport zone. It comprises three main parts: (1) the meteorological station that includes other sensors (i.e., temperature sensors) and a rain gauge that registers rainfall with a 5-min temporal resolution; (2) the station that has eight geophones, an ultrasonic device, a radar sensor, and a video camera to detect and characterize the flow dynamics of the events; and (3) the infiltration stations that include sensors to measure the soil moisture and water pressure (Fig. 1a). Detailed information on the monitoring system can be found in Hürlimann et al. (2014).

Between September 2009 and December 2015, 29 events were registered, averaging more than four events per year.

The meteorological characteristics of the area are particularly influenced by the proximity of the Mediterranean Sea and the presence of the Pyrenees. The mean annual precipitation in this part of Catalonia ranges between 800 and $1200 \mathrm{~mm}$ (Hürlimann et al. 2016). The mean annual precipitation registered by the rain gauge of the monitoring station is $945 \mathrm{~mm}$ per year, with a minimum value of $700 \mathrm{~mm}$ and a maximum of $1100 \mathrm{~mm}$.

\section{Materials and methods}


The main data used in the analysis consist of two time series: (1) the rainfall data from September 2009 to December 2015, measured at a time step of $5 \mathrm{~min}$, and (2) the volume of the DF/DFD events measured during the same period. The volume assessment for each DF/DFD was principally performed by the interpretation of the monitoring data and cross-checked by the post-event morphologic observations along the channel and on the fan. In particular, the total volume was estimated by the monitoring data including peak flow area, flow velocity, and duration event duration. The flow area was determined by the flow height measured at the ultrasonic device and the information of the cross-sectional shape measured during the field campaigns. The flow velocity and the duration were calculated by geophone and ultrasonic sensor data (for detailed explanations, see Hürlimann et al. 2014).

The time series data registered by the rain gauge of the meteorological station were not complete because of functional problems of the instrument. Therefore, we used the data sets registered by a nearby rain gauge to fill the gaps in our time series. This second rain gauge is located at the hydropower dam of Baserca (approximately $3.2 \mathrm{~km}$ north of the Rebaixader catchment) and has a registration time step of $15 \mathrm{~min}$. We checked if there was a correlation between the series of the two rain gauges, and the results showed that the two rainfall series are similar. Therefore, we filled the gaps of our station with the values of the neighboring station.

The complete rainfall series data of the Rebaixader rain gauge were analyzed by $\mathrm{R}$ software (R Development Core Team 2005). With a script that reads the date and time of every registered value, we were able to find all the gaps in the initial time series data. Once these gaps were identified, they were filled using the rainfall data registered by the Baserca rain gauge. In particular, the gaps of 2013 were very large because 6 months were completely missing, whereas in the other years, there were sometimes little gaps (e.g., the missing of one single data) that mostly corresponded to periods of no rain. In the few cases in which a rainfall episode was missing, we checked and filled the values with the ones of the Baserca rain gauge. The final resolution of the resulting time series is $15 \mathrm{~min}$ for 2013 and 5 min for the other years. It is important to evidence that the analysis might be affected by spatially varying rainfalls which could have been not captured by the monitoring station (e.g., Hrachowitz and Weiler 2011).

$\mathrm{AQ} 4$

AQ5

The next step of the analysis consisted of the identification of every rainfall event inside the time series registered by the rain gauge. From these time series, the rainfall events were defined by identifying a 1-h interval without 
precipitation before and after the event. This interval is similar to the ones used in companion studies (e.g., Deganutti et al. 2000; Badoux et al. 2009; Abancó et al. 2016). We always considered the entire rainfall event, from the beginning to the end of the rain regardless to the fact that a DF/DFD event was triggered or not. We excluded the events with a total precipitation of less than $4 \mathrm{~mm}$. This limit was defined because the minimum triggering rainfall measured in the catchment was found to be $4.7 \mathrm{~mm}$ (Table 1). Therefore, we considered all the rainfall events equal or higher than $4 \mathrm{~mm}$, also in the case they did not trigger a DF/DFD event. In total, we extracted 244 rainfall events and 22 of them corresponded to a DF/DFD event.

\section{Table 1}

Variables calculated for every debris flow and debris flood (DF/DFD) event registered in the AQ6

\begin{tabular}{|c|c|c|c|c|c|c|c|}
\hline \multirow[b]{2}{*}{ Date } & \multirow{2}{*}{$\begin{array}{c}\text { Type } \\
\text { of } \\
\text { debris }\end{array}$} & \multirow{2}{*}{$\begin{array}{c}\text { Volume } \\
\left(\mathbf{m}^{3}\right)\end{array}$} & \multirow{2}{*}{$\begin{array}{c}\text { Recharge } \\
\text { period } \\
\text { (days) }\end{array}$} & \multicolumn{4}{|c|}{ Sediment recharge period var } \\
\hline & & & & $\begin{array}{c}P_{\text {tot }} \\
(\mathrm{mm})\end{array}$ & $\begin{array}{c}I_{30 \max } \\
\left(\mathrm{mm}^{-1} \mathrm{~h}^{-1}\right)\end{array}$ & $\begin{array}{c}I_{15 \max } \\
\left(\mathrm{mm}^{-1} \mathrm{~h}^{-1}\right)\end{array}$ & $\begin{array}{r}\mathbf{E I} \\
(\mathbf{M J}\end{array}$ \\
\hline $01 / 09 / 2009$ & Flood & 1000 & - & - & - & - & - \\
\hline $25 / 03 / 2010$ & Flow & 2100 & 205 & 442.60 & 20.60 & 24.00 & 763 \\
\hline $11 / 07 / 2010$ & Flow & 12,500 & 108 & 128.30 & 14.20 & 25.60 & 169. \\
\hline $21 / 07 / 2010$ & Flood & 1000 & 10 & 0 & 0 & 0 & 0 \\
\hline $09 / 10 / 2010$ & Flood & 1600 & 80 & 94.90 & 13.60 & 14.40 & 186. \\
\hline $13 / 07 / 2011$ & Flood & 700 & 277 & 409.50 & 15.60 & 24.80 & 405 \\
\hline 05/08/2011 & Flood & 2800 & 23 & 0 & 0 & 0 & 0 \\
\hline 05/08/2011 & Flood & 2500 & 0 & 0 & 0 & 0 & 0 \\
\hline 07/08/2011 & Flood & 350 & 2 & 0 & 0 & 0 & 0 \\
\hline $03 / 11 / 2011$ & Flood & 600 & 88 & 126.00 & 13.40 & 49.20 & 200 . \\
\hline $27 / 06 / 2012$ & Flow & 4000 & 237 & 240.60 & 13.80 & 17.20 & 282 \\
\hline $04 / 07 / 2012$ & Flow & 16,200 & 7 & 0 & 0 & 0 & 0 \\
\hline 05/07/2012 & Flood & 1000 & 1 & 0 & 0 & 0 & 0 \\
\hline $05 / 06 / 2013$ & Flood & 2100 & 335 & 426.20 & 20.20 & 33.60 & 404. \\
\hline $17 / 06 / 2013$ & Flood & 100 & 12 & 22.40 & 10.00 & 19.20 & 31.6 \\
\hline $23 / 07 / 2013$ & Flood & 600 & 36 & 74.80 & 19.20 & 35.20 & 154 \\
\hline $27 / 07 / 2013$ & Flood & 450 & 4 & 0 & 0 & 0 & 0 \\
\hline $06 / 09 / 2013$ & Flood & 941 & 41 & 135.20 & 24.00 & 46.40 & 326. \\
\hline
\end{tabular}




\begin{tabular}{|c|c|c|c|c|c|c|c|}
\hline \multirow[b]{2}{*}{ Date } & \multirow{2}{*}{$\begin{array}{c}\text { Type } \\
\text { of } \\
\text { debris }\end{array}$} & \multirow[b]{2}{*}{$\begin{array}{l}\text { Volume } \\
\text { (m ) }\end{array}$} & \multirow{2}{*}{$\begin{array}{c}\text { Recharge } \\
\text { period } \\
\text { (days) }\end{array}$} & \multicolumn{4}{|c|}{ Sediment recharge period var } \\
\hline & & & & $\begin{array}{c}P \\
(\mathbf{m m})\end{array}$ & $\left.\begin{array}{ccc}I & & \\
(\mathrm{~mm} & h\end{array}\right)$ & $\left.\begin{array}{ccc}I & & \\
(\mathbf{m m} & h\end{array}\right)$ & $\begin{array}{r}\mathbf{E I} \\
(\mathbf{M J}\end{array}$ \\
\hline $20 / 07 / 2014$ & Flood & 1000 & 317 & 427.50 & 18.20 & 23.60 & 599. \\
\hline $25 / 07 / 2014$ & Flood & 1150 & 5 & 0 & 0 & 0 & 0 \\
\hline $13 / 08 / 2014$ & Flow & 14,000 & 19 & 0 & 0 & 0 & 0 \\
\hline $31 / 07 / 2015$ & Flood & 400 & 352 & 438.60 & 32.40 & 58.40 & 859. \\
\hline
\end{tabular}

Using the extracted rainfall events, we calculated multiple variables related to the precipitation characteristics for each of the DF/DFD events: (1) total precipitation $\left(P_{\text {tot }}\right),(2)$ total duration $\left(D_{\text {tot }}\right),\left(\begin{array}{ll}3 & 2\end{array}\right)$ maximum intensity within a 30-min period during the event $\left(I_{30 \text { max }}\right),\left(\begin{array}{ll}4 & 3\end{array}\right)$ maximum intensity within a 15-min period during the event $\left(I_{15 \max }\right),\left(\begin{array}{ll}5 & 4\end{array}\right)$ total kinetic energy $\left(E_{\mathrm{k}}\right)$, and corresponding Erosion Index of the event $\left(\mathrm{EI}_{\Delta t \max }\right)($ Table 1). This last characteristic expresses the rain erosivity adopted by Wischmeier and Smith (1978) to calculate the soil loss for a given soil erodibility. This erosivity is calculated as the product of the total kinetic energy of the rainfall event $\left(E_{\mathrm{k}}\right)$ and the maximum hourly intensity observed within a 30-min period during the event. Originally, this parameter was created to study the temporal range of one or several years (Panagos et al. 2015). This means that the Erosion Index was calculated as the summation of every rain erosivity value calculated for every rainfall event of the considered year/period. Nevertheless, we used the index with different time spans: (1) we considered the rain erosivity value of each rainfall event individually, without making any summation $\left(\mathrm{EI}_{30 \mathrm{TRIG}}\right)$, and (2) we calculated the Erosion Index of every recharge period as the summation of the erosivity values of all the rainfall events registered between two consecutive $\mathrm{DF} / \mathrm{DFD}$ events $\left(\mathrm{EI}_{30 \mathrm{RECH}}\right)$.

Different equations have been developed for the calculation of the rainfall erosivity (e.g., Wischmeier and Smith 1978; Kinnell 2010; Panagos et al. 2014, 2015). Originally, the equation proposed by Wischmeier and Smith (1978) has been developed to study lowland/hilly areas where the soil is more suitable for farmers (e.g., loam). Therefore, they made the following assumptions the following assumption for the erosion occurrence: : (1) total rainfall depth higher than $13 \mathrm{~mm}$ and (2) at least $6 \mathrm{~mm}$ of rain within $15 \mathrm{~min}$. In our study, the environment is completely different, because we are not in a flat zone and our catchment has a significant slope gradient. Moreover, the sediment that composes the surface of our study area is different from that of a cultivated 
zone. Therefore, the kinetic energy of rainfall needed here is different from the one needed on a flat cultivated area. Hence, we used different assumptions from the original ones based on event observations (as stated above): total rainfall depth of a significant event $\geq 4 \mathrm{~mm}$ without using the limit of $6 \mathrm{~mm}$ in $15 \mathrm{~min}$. Nevertheless, the equation used in our study is the original equation proposed by Wischmeier and Smith (1978).

The steps for the computation of the $\mathrm{EI}_{\Delta t \text { max }}$ are as follows:

- Computation of the kinetic energy the specific kinetic energy $\quad\left(e_{\mathrm{k}}\right.$, MJ ha ${ }^{-1} \mathrm{~mm}^{-1}$ ) of every rainfall time step $(\Delta t)$ during the event using the following equation (Wischmeier and Smith 1978):

$$
e_{\mathrm{k}}=0.119+0.0873 \log _{10} i_{\Delta t}
$$

where $i_{\Delta t}$ is the 15 - or 30 -min intensity $\left(\mathrm{mm} \mathrm{h}^{-1}\right)$ of each time step of computation.

Equation (1) must be applied by entering a constant value of $76 \mathrm{~mm} \mathrm{~h}^{-1}$ if $i_{\Delta t}$ is greater than this value. This equation has been used and verified for many decades by the research community, and it has been found that it can be theoretically deduced and it is structurally correct (Carollo et al. 2016). Moreover, it provides an energy estimate that is close to that obtained by Van Dijk et al. (2002); see p. 7, Figure 3) (2002; see p. 7, Fig. 3) based on a comprehensive review of published studies.

- Calculation of the kinetic energy of a single time step $\left(E_{\mathrm{k} i}, \mathrm{MJ} \mathrm{ha}^{-1} \mathrm{~mm}^{-1}\right)$ with the following equation:

$$
E_{\mathrm{k} i}=P e_{\mathrm{k}}
$$

where $P$ is the rainfall $(\mathrm{mm})$ registered in the considered time step.

- Computation of the total kinetic energy $\left(E_{\mathrm{k}}, \mathrm{MJ} \mathrm{ha}^{-1} \mathrm{~mm}^{-1}\right)$ of the rainfall event

$$
E_{\mathrm{k}}=\sum E_{\mathrm{k} i}
$$

- Finally, the erosion indices $\left(\mathrm{EI}_{\Delta t \max }, \mathrm{MJ} \mathrm{mm}^{-1} \mathrm{ha}^{-1} \mathrm{~h}^{-1}\right)$ are calculated as follows: 


$$
\mathrm{EI}_{\Delta t \max }=I_{\Delta t \max } E_{\mathrm{k}}
$$

where $\Delta t$ indicates $\Delta t(30 \mathrm{~min})$ indicates.. the reference duration. In fact, we ealculated the Erosion Index using both the 30 -min maximum intensity $\left(I_{30}\right.$ max $\left.\mathrm{mm} \mathrm{h}^{-1}\right)$ and the 15 -min maximum intensity $\left(t_{15 \mathrm{max}}, \mathrm{mmm} \mathrm{h}^{-1}\right)$.

The $\mathrm{EI}_{\Delta t \text { max }}$ values are used for two different analyses: (1) the single $\mathrm{EI}_{\Delta t \text { max }}$ values of every rainfall event from the start to the end of the rain are considered as the "triggering" values $\left(\mathrm{EI}_{\Delta t \text { TRIG }}\right)$, and (2) the summation of the $\mathrm{EI}_{\Delta t \text { max }}$ values of all the rainfall events between two consecutive DF/DFD values is considered as the $\mathrm{EI}_{\Delta t \text { max }}$ of the recharge period $\left(\mathrm{EI}_{\Delta t \mathrm{RECH}}\right)$.

The values of the $\mathrm{EI}_{\Delta t} \mathrm{TRIG}_{\mathrm{T}}$ and the $\mathrm{EI}_{\Delta t \text { RECH }}$ versus DF/DFD volumes are processed to verify if there is some correlation between the soil erosion caused by rainfall and the amount of mobilized volume. The $\mathrm{EI}_{\Delta t \text { TRIG }}$ values indicate if the volume of the DF/DFD event is conditioned by the rain erosivity of the triggering rainfall event, affecting the triggering area. The $\mathrm{EI}_{\Delta t \mathrm{RECH}}$ corresponds to the cumulated rainfall erosivity during the recharge period. As outlined in the "Introduction," "Introduction", different authors (i.e., Bovis and Jakob 1999; Brayshaw and Hassan 2009) explain that there are two types of DF/DFD catchments: "supply-unlimited" catchments, where there is always available sediment, and "supply-limited" catchments, where the morphological characteristics are different so there is not always available sediment to trigger DF/DFD events. The Rebaixader catchment is considered as supply-unlimited, but we wanted to investigate if also in this type of basin, the period between two DF/DFD events (recharge period) influences the next torrential event.

We have no topographic measurements or data describing the sediment recharge in the period between two consecutive DF/DFD events. Therefore, we used the volume of each DF/DFD event as a proxy variable of sediment availability before the same DF/DFD event. The initial assumption was that a greater recharging rainfall would correspond to a larger volume of the following event. Therefore, we distinguished between recharging variables, which influence the recharge period and do not directly affect the triggering of the DF/DFD, and triggering variables, which directly concern the triggering precipitations. We carried out a back analysis considering the volume of the DF/DFD as an indirect measure of the sediment recharge that characterizes the recharge period before the DF/DFD occurrence. This is a simplified model because we are assuming that all of the sediment available to a DF/DFD event is mobilized when the rain threshold is exceeded. The purpose of this simplification is to understand if there 
is a direct correlation between the different energetic features of precipitation and sediment recharge.

Following the findings of the work of Abancó et al. (2016), we also analyzed how the 15- and 30-min intensity and $\mathrm{EI}_{\Delta t \text { max }}$ of the triggering event directly influence the volume of the torrential event, reducing the significance of the role of the recharge period.

Finally, the last analysis was conducted to verify if it is possible to extract a DF/DFD triggering threshold by coupling the 30-min intensity $\left(I_{30 \max }\right)$ with the total $E_{\mathrm{k}}$ of each rainfall event.

\section{Results}

\section{Seasonal behavior of the catchment}

Multiple variables contribute to the triggering mechanism: the antecedent $\mathrm{DF} / \mathrm{DFD}$ volume, the triggering rainfall characteristics, and the length of the recharge period, among others. Therefore, it is important to describe the typical behavior of the Rebaixader catchment. Figure 3 shows an overview of the event history of the Rebaixader catchment during the years analyzed. The total amount of precipitation is compared with the total amount of sediment volume mobilized by the torrential flows between the summer of 2009 and the end of 2015 . Generally, every year can be divided into four typical periods: (1) December to February (winter), (2) March to May (spring), (3) June to August (summer), and (4) September to November (autumn). Figure 3a shows that no DF/DFD events were triggered during winter. During spring, a single DF/DFD event was triggered (25 March 2010). Summer was the most active period, with $77 \%$ of all $\mathrm{DF} / \mathrm{DFD}$ events occurring in that period. Finally, in autumn, the number of triggered DF/DFD events was slightly lower (18\%) than in the summer. From Fig. 3b, c, it can be concluded that the mobilized sediment trend does not follow the same distribution as the precipitation. This means that the total rainfall amount during the recharge period is not enough to explain or predict the behavior of the sediment supply and mobilization. Therefore, to consider the seasonal behavior, it is important to individually analyze each DF/DFD event. A summary of this description and a detailed examination can be found in Online Resource 1, named "Supplementary data: description of the DF/DFD events."

\section{Fig. 3}

Distribution of the rainfall and volume of the DF/DFD events in the years of the analysis. a Daily rainfall versus volume of the single events. b Monthly rainfall versus cumulated monthly DF/DFD volume. c Seasonal rainfall versus cumulated seasonal DF/DFD volume 

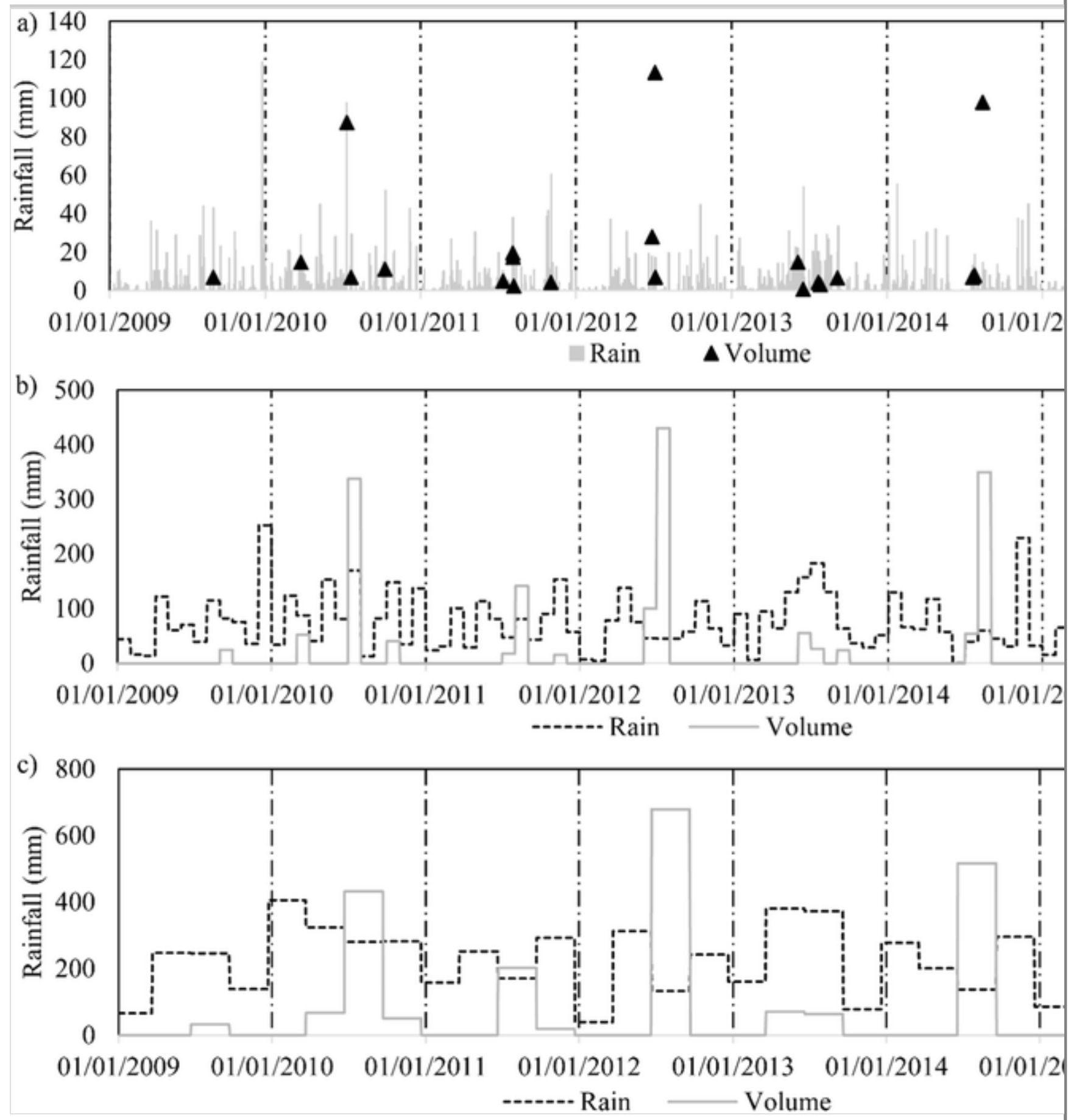

AQ7

Another analysis of the influence of the recharge period on the event volumes $(V)$ can be seen in Fig. 4. Here, the comparison between the volumes of two consecutive DF/DFD events, normalized by the corresponding $I_{30 \text { max }}$ of the triggering phase, is shown. The event pairs that occurred less than 20 days from each other are reported. In the case of the occurrence of three close events (August 2011), the intermediate one is plotted two times (event numbers 2 and 3 in Fig. 4). The general trend is that the normalized second event was smaller than the normalized first event, and in only two cases (DF event numbers 4 and 9 in Fig. 4), the second event was significantly larger than the first one. The DF 
event range of the normalized volume $\left(V / I_{30 \text { TRIG }}\right)$ of close events varies between 156 and $707 \mathrm{~m}^{3} \mathrm{~mm}^{-1} \mathrm{~h}^{-1}$, while that of DFD events is $10-150 \mathrm{~m}^{3} \mathrm{~mm}^{-1} \mathrm{~h}^{-1}$ (Fig. 4).

\section{Fig. 4}

Comparison between the paired normalized volume (normalized by $I_{30 \text { TRIG }}$ ) of a DF/DFD event and the subsequent DF/DFD event that occurred within a time span of less than 20 days. In the table, shown are the data and type of event regarding the coupled events

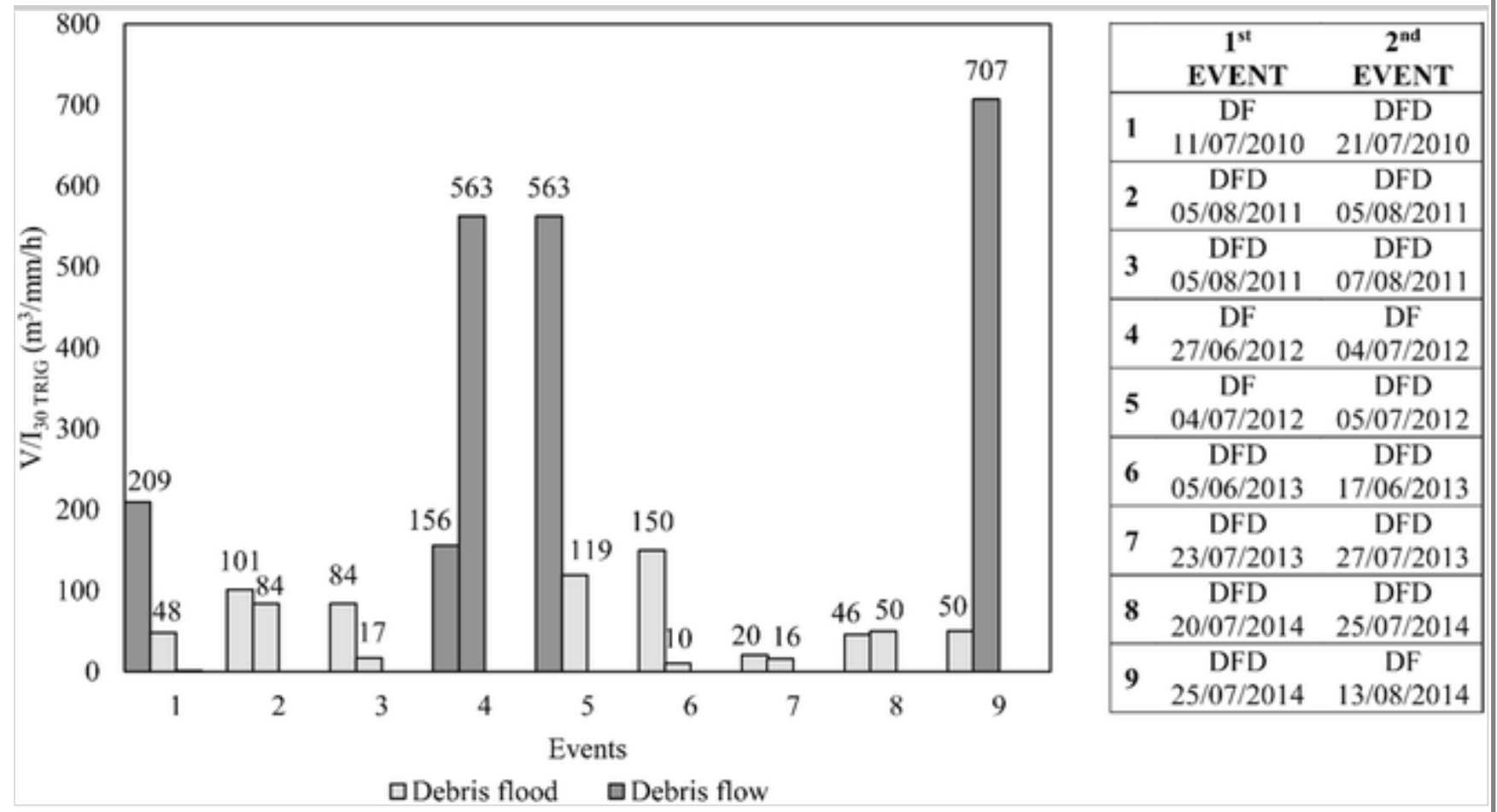

\section{Influence of the rainfall characteristics on the DF/DFD events}

From the DFD events of the $\mathrm{EI}_{30 \mathrm{RECH}}$ (i.e., the Erosion Index of the recharge period) versus volume in Fig. 5, it can be observed that the volume does not follow a particular trend, and it seems completely independent from the Erosion Index of the recharge period. In fact, the correlation coefficient $(\rho)$ calculated between the two variables is of -0.24 , meaning that there is a very weak negative correlation. Interestingly, for the DF events, the correlation between the DF volume and the $\mathrm{EI}_{30 \mathrm{RECH}}$ is strongly negative $(\rho=-0.88)$, but in this case, it is important to notice that we are considering only five points and so this statistical metric is not so reliable. Nine of the DF/DFD events are not visible in the graph because for those events, there was no intermediate rainfall since the previous event; this is the reason why they have $\mathrm{EI}_{30 \mathrm{RECH}}$ values equal to zero.

Fig. 5 There is an error in the x-axis title. We attach the corrected Fig. 5. 
Correlation between the Erosion Index calculated for the recharge period and the volume of the corresponding DF/DFD event. The overall correlation coefficient between the two variables is $\rho=-0.24$, whereas the correlation coefficient of the debris flow data is $\rho=-0.88$

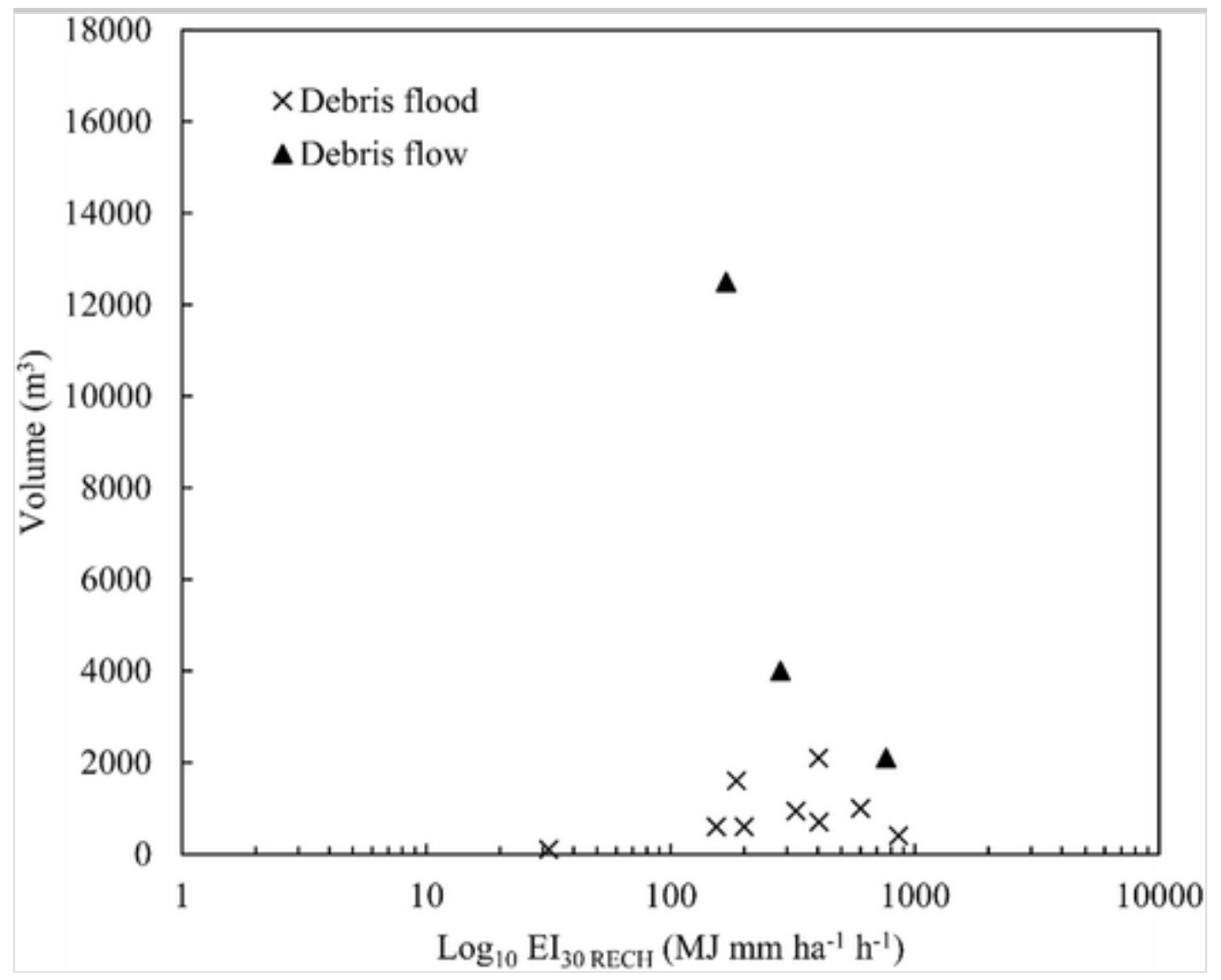

From observations of the $\mathrm{EI}_{30 \text { TRIG }}$ results (i.e., the Erosion Index of the triggering rainfall event), it can be noted that there is a moderate positive correlation $(\rho=0.40)$ with the volume of the events (Fig. 6). This result suggests that the "soil instability" caused by the overall triggering feature of the rainfall influences the magnitude of the event. This means that with greater rainfall energy, the volume of the mobilized debris is larger. Moreover, the $\mathrm{EI}_{30 \text { TRIG }}$ is composed of both the rainfall quantity and the rainfall intensity, so it simultaneously considers different rainfall characteristics. The range of the $\mathrm{EI}_{30}$ TRIG is very close to the range of $\mathrm{EI}_{30 \mathrm{RECH}}$. More precisely, the first varies from approximately $10 \theta$ to $1000 \mathrm{MJ} \mathrm{mm}^{-1} \mathrm{ha}^{-1} \mathrm{~h}^{-1}$ and it is slightly larger than that of the $\mathrm{EI}_{30 \mathrm{RECH}}$ (Figs. 5 and 6).

Fig. 6 There is an error in the x-axis title. We attach the corrected Fig. 6.

Correlation between the triggering Erosion Index and the volume of the corresponding DF/DFD event. The overall correlation coefficient between the two variables is $\rho=0.40$, whereas the correlation coefficient of the debris flow data is $\rho=0.26$ 


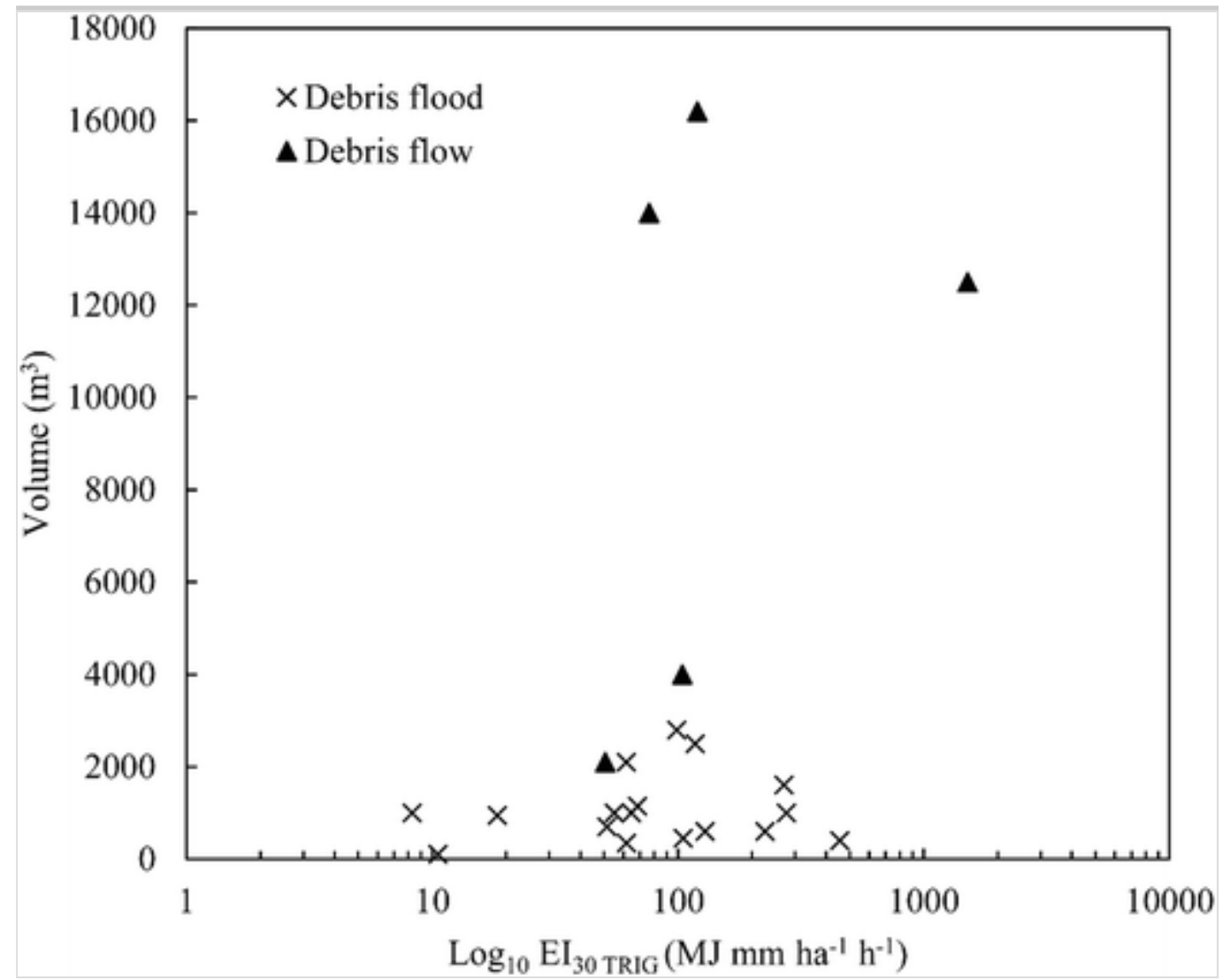

Considering the results, it seems that in this catchment, there is not a significant triggering threshold of rainfall, since there are some DF/DFD events that are triggered by the smallest rainfall events recorded. The minimal triggering rainfall occurred on 5 July 2012 and accumulated only $4.70 \mathrm{~mm}$ during $80 \mathrm{~min}$ (Table 1).

Another variable that provides a moderate correlation with the DF/DFD volume is the rainfall intensity, $I_{\Delta t \text { max }}$ (overall $\rho=0.28$ in Fig. 7a and overall $\rho=0.39$ in Fig. 7b). For the DFD events, there is a very weak correlation, since the volume data are sparse (Fig. 7). However, for the DF events, it can be seen that a higher rain intensity corresponds to a greater flow volume. In particular, the correlation between $I_{15 \text { max }}$ and volume is $\rho=0.52$, whereas the correlation between $I_{30 \text { max }}$ and volume is $\rho=0.41$. Therefore, the link with the volume is slightly higher for $I_{15 \text { max }}$ (a) than for $I_{30 \text { max }}$ (b), and in both cases, we can conclude that the volumes of the DFD events are mostly below the lower limit of the DF volumes (approximately $2000 \mathrm{~m}^{3}$ ). Moreover, it is interesting to notice that the triggering intensities of the DF events are not different from those of the DFD events (Fig. 7). This means that a rainfall event can trigger either a DF or a DFD event and confirms our hypothesis that the switch from a DFD to a DF event should be explained by other factors.

Fig. 7 There is an error in the x-axis title. We attach the corrected Fig. 7. 
Correlation between the maximum intensity within $15 \mathrm{~min}(\mathbf{a})$ and $30 \mathrm{~min}(\mathbf{b})$ and the volume of the corresponding DF/DFD event, fitting line for only the DFs. In a, the overall correlation coefficient between the two variables is $\rho=0.28$, whereas the correlation coefficient of the debris flow data is $\rho=0.52$. In $\mathbf{b}$, the overall correlation coefficient between the two variables is $\rho=0.39$, whereas the correlation coefficient of the debris flow data is $\rho=0.41$
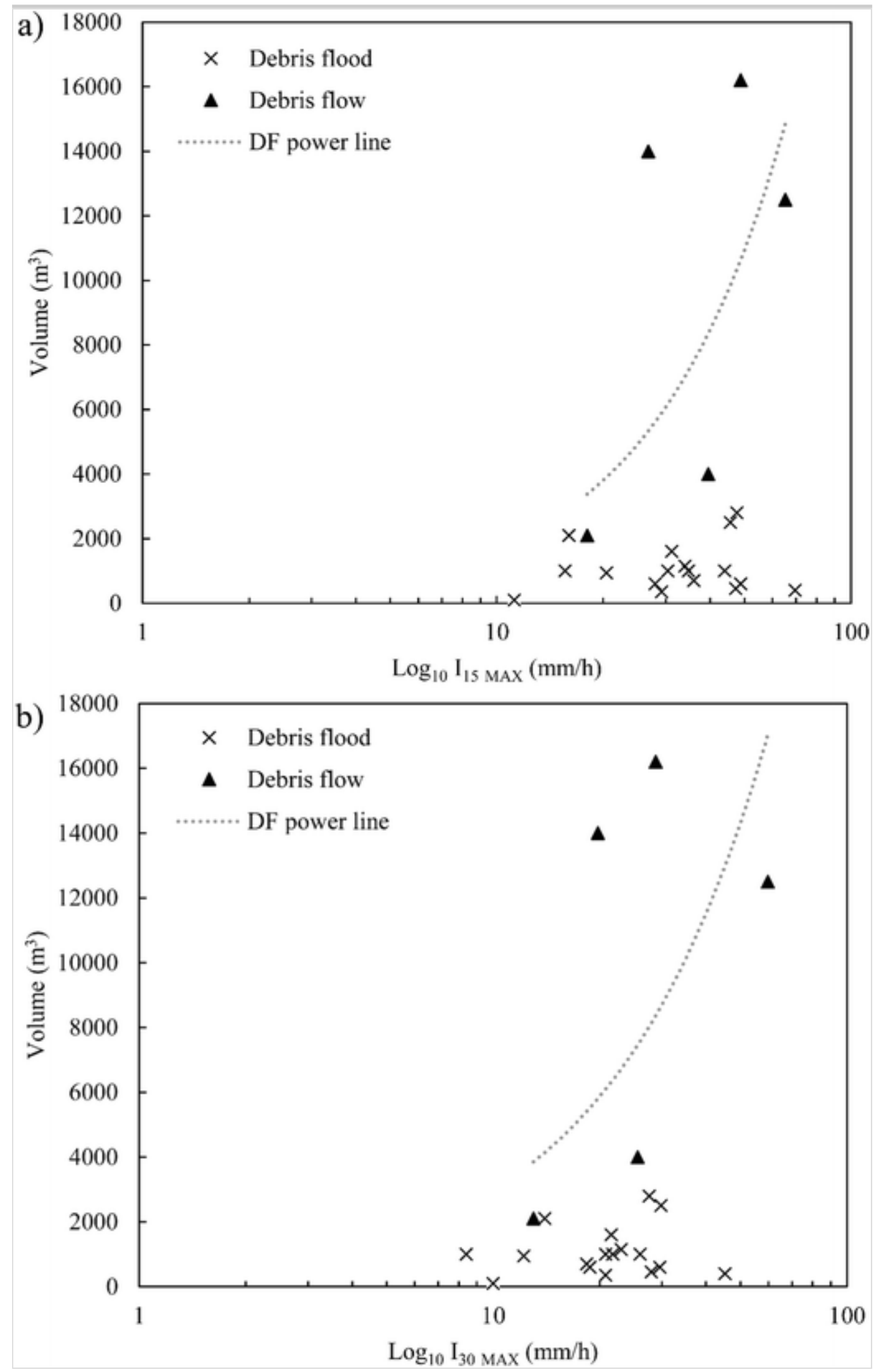
An interesting correlation can be observed between the total $E_{\mathrm{k}}$ (calculated for each rainfall event) and $I_{30 \max }$ in Fig. 8. The equation $I_{30 \max }=9.86 E_{\mathrm{k}}{ }^{0.52}$ (Fig. 8) interpolates the median coupled values median upper values $\left(E_{\mathrm{k}}, I_{30}\right.$ max ) that triggered a DF/DFD event. This threshold discriminates the values for which the probability of DF/DFD triggering is very high (above the line) from the values for which the DF/DFD triggering is improbable (below the line).

Fig. 8 There was an error in the unit of $E_{k}$ inside Fig.8. We attached the corrected Fig.8. Differences between the rainfall events that triggered and did not trigger DF/DFD events combining the kinetic energy $\left(E_{\mathrm{k}}\right)$ and the 30 -min maximum intensity $\left(I_{30}\right.$ max). The "no trig" data correspond to the rainfall events that did not trigger any torrential event. The straight line defines the threshold to distinguish between high DF/DFD triggering probability (above the line) and low DF/DFD triggering probability (below the line)

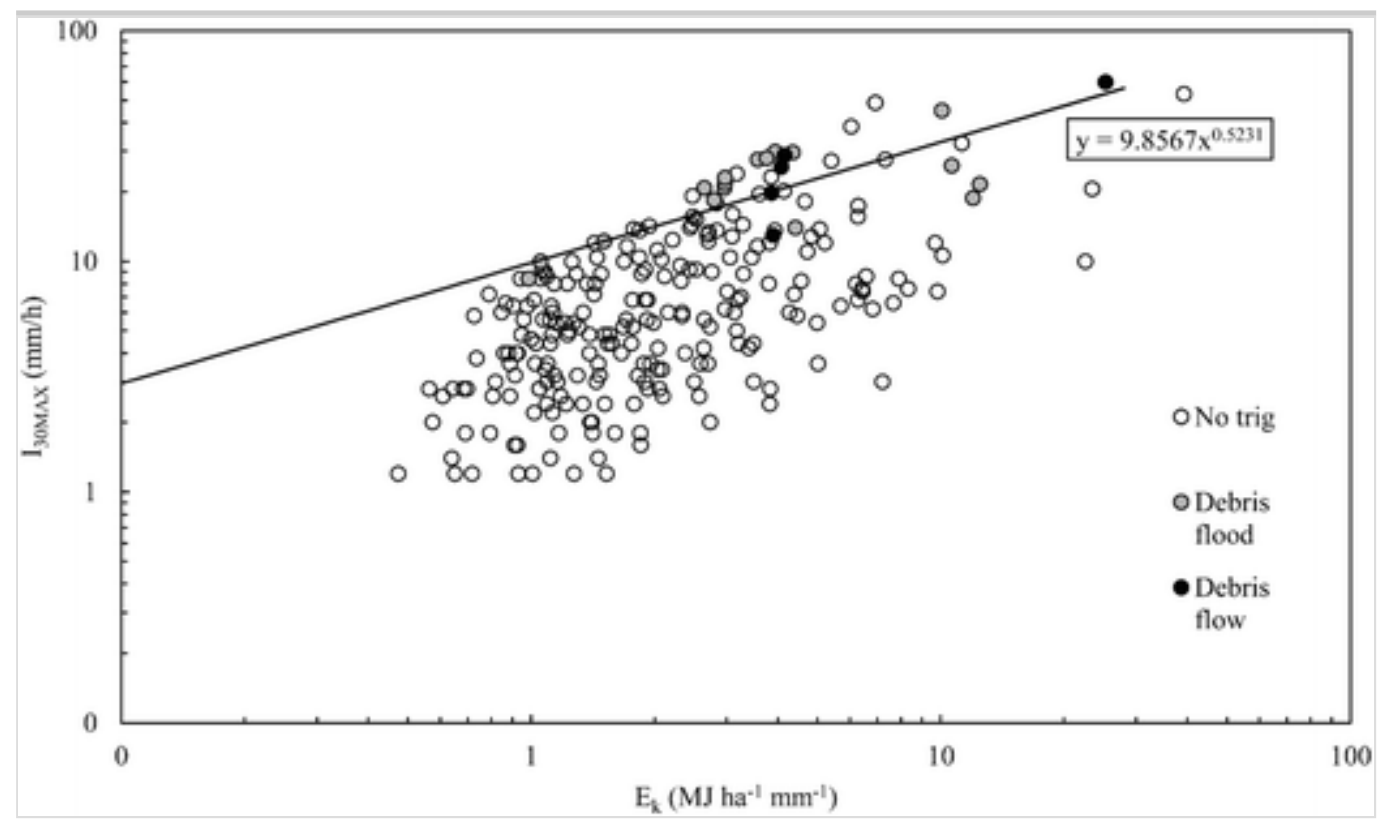

\section{Discussion}

The first hypothesis to test of the present work was that a correlation between the rainfall during the recharge period and the volume of the next event existed. In particular, we hypothesized that a greater rainfall amount during the recharge period would correspond to a greater available (and consequently mobilized) sediment load. To study this correlation, we analyzed all rainfall events using the $\mathrm{EI}_{\Delta t \text { max }}$ variable. The $\mathrm{EI}_{\Delta t \text { max }}$ incorporates the rainfall duration $(D)$, the rainfall intensity maximum rainfall intensity $\left(I_{\Delta t \text { max }}\right)$, and the total energetic contribution of the rainfall $\left(E_{\mathrm{k}}\right)$. Therefore, it strongly expresses the rainfall characteristics and its capacity to produce sediment. The $I_{\Delta t \text { max }}$ plays an important role. In fact, 
a rainfall event that not only has a short duration and relatively low total rainfall depth but also a high intensity can result in an $\mathrm{EI}_{\Delta t \max }$ index much higher than that of a rainfall event with very long duration and low intensity (Xie et al. 2016). This is a good feature of the selected indicator because we know that a $\mathrm{DF} / \mathrm{DFD}$ event is typically triggered by short and strong rainfall events (Floris et al. 2010), and so, it is clear that these are the events that more easily entrain and transport sediments downstream.

Owing to the presence of the dominant erodible area in the catchment (Fig. 2) and the evident secondary role in terms of sediment storage of the short DF/DFD transport reach of the torrent, we expected to find some correlation between the $\mathrm{EI}_{\Delta t \mathrm{RECH}}$ and the volume of the following DF/DFD event, but no significant trend has been observed. This fact could prove that basin preparation due to nontriggering rainfalls during rest periods could have a small effect on future sediment volumes of DF/DFD events in situations comparable to that of the Rebaixader torrent, being the sediment recharge partially obliterated by the rain energy at the triggering. The lack of correlation demonstrates that other stochastic factors play a more crucial role in the preparation of new erodible material than rainfall during the recharge period.

It is worth stressing that our experimental basin is characterized by very frequent DF/DFD events, and so, the recharge periods are in the order of months. Therefore, the first events of every year are usually characterized by higher $\mathrm{EI}_{\Delta t}$ RECH because of both the longer time since the last event and the considerably greater volume of water input during the recharge period. Moreover, different studies proved the importance of freeze-thaw cycles during winter, in the creation of new available sediment (e.g., Regues and Gallart 1999; Imaizumi et al. 2006; Theule et al. 2012). A catchment with a recharge period in the order of tens to several tens of years (supply-limited type) would probably produce different results, and the erosive work of the precipitation could be more effective.

In contrast, a positive correlation between the $\mathrm{EI}_{30 \text { TRIG }}$ and the volume of the triggered flow $(\rho=0.40)$ is evidenced by the dominance of the energetic/episodic impulse both on the triggering conditions (Fig. 8) and on the volume magnitude (Fig. 6), supporting our previous statement on the low effect of sediment recharge. $I_{30 \text { max }}$ and $I_{15 \text { max }}$ of the triggering rainfall events (Fig. 7) show a lower correlation with the DF/DFD volume ( $\rho=0.28$ for $I_{15 \max }$ and $\rho=0.39$ for $I_{30 \max }$ ), confirming that the DF/DFD magnitudes remain weakly to moderate weakly/moderately precipitation dependent. Other studies have also demonstrated the small role of precipitations on the magnitude of the triggered event (e.g., Gartner et al. 2008; Bel et al. 2017). Our conclusion on this issue, in 
the case of the Rebaixader torrent catchment, is that using the triggering rainstorms of a given return period (i.e., derived from the hydrological statistics of rain data) to estimate the corresponding/equivalent return periods of expected DF/DFD volumes should still be done cautiously.

Since the rain intensity values, if used alone, are not capable of discriminating between the type of event (DF or DFD), the previous conclusion is corroborated and in accordance with the results found by Cannon et al. (2001). In the types of basins that behave like the typical supply-unlimited catchment (e.g., the Rebaixader torrent catchment where a single rainfall event intensity can trigger DF/DFD events within a wide volume range), a discriminatory criterion that is based on the precipitation pattern and intensity to forecast low-volume DFDs rather than high-volume DFs seems to be extremely difficult to construct. This last issue emerges clearly from the data of our study catchment, where a discrimination would have been useful if first conditioned on the process type because of the difference in sediment volumes (DF or DFD in the Rebaixader catchment; Figs. 5 and 6). For example, a rainfall event with a very low intensity, such as the one triggered on 5 July $2012\left(8.4 \mathrm{~mm} \mathrm{~h}^{-1}\right)$, was capable of triggering a DFD; conversely, events such as those that occurred on 11 July 2010, 23 July 2013, and 31 July 2015 were triggered by high rainfall intensities (Table 1).

Additionally, the results obtained by Theule et al. (2012) showed that the minimum rainfall intensity that causes the mobilization of sediments in the Manival torrent is not very high $\left(7 \mathrm{~mm} \mathrm{~h}^{-1}\right)$, which is very similar to the minimum rainfall intensity measured in the Rebaixader catchment (Table 1). Furthermore, our results highlight that the same rainfall event can trigger, without discrimination, events with sediment volumes that range over at least 1 order of magnitude. For example, if the range of the triggering $I_{15 \text { max }}$ rainfalls varies from approximately 10 to $70 \quad 10$ to $25 \quad \mathrm{~mm} \mathrm{~h}^{-1}$ (Table 1) Table 1 and Figure 7a ,., these similar rainfall events can trigger DF/DFD events from 2000 up to $14,000 \mathrm{~m}^{3}$. The same relationship can also be observed for greater $I_{15 \max }$ values.

Unlike the difficulty of forecasting process-type process type (DF or DFD) eatehments, the threshold line from $I_{30 \text { max }}$ and $E_{\mathrm{k}}$ (Fig. 8) is capable of improving the distinction between triggering and non-triggering rainfall events. In fact, the results obtained by Abancó et al. (2016) using the classic intensityduration graphics resulted in a value of false positives of $5.6 \%$. In our case, 16 triggering rainfall events, on a total of 22 , lie above the defined threshold (Table 2 ), meaning that the sensitivity of the model is of 0.73 (Beguería 2006), whereas 210 non-triggering rainfall events, out of a total of 222 , lie below the threshold 
(Table 2), meaning that the specificity of the threshold is of 0.95 (Beguería 2006). Therefore, the defined threshold has a high capacity of discriminating the non-triggering events. In fact, only $5.0 \%$ of non-triggering rainfall events lie above the threshold (false positives), whereas . Whereas it is moderately capable of discriminating the triggering rainfall events; in fact, the $27.0 \%$ of triggering events lie below the threshold (false negatives).

\section{Table 2}

Confusion matrix of the triggering and non-triggering rainfall events based on the threshold relation in Fig. $8\left(I_{30 \max }=9.86 E_{\mathrm{k}}{ }^{0.52}\right)$

\begin{tabular}{|c|c|c|c|}
\hline & Triggering events & Non-triggering events & \\
\hline Over threshold & 16 & 12 & 28 \\
\hline \multirow[t]{2}{*}{ Below threshold } & 6 & 210 & 216 \\
\hline & 22 & 222 & \\
\hline
\end{tabular}

The record of temporal proximity between two or more DF/DFD events seems to add some additional information on the event sequence in the Rebaixader catchment. In fact, in In nine cases out of a total of 22, the next event occurred less than 20 days after the previous one. In these cases, our hydrologic recharge period was null because the total rainfall depth in the interval between the two events is $0 \mathrm{~mm}$ (Table 1). Looking, in particular, at the DFD events, it seems that the standard scenario was that of a cleaning behavior, meaning that the second event was smaller than the first one so it removed only a small volume of sediment left by the previous event. In only two cases, the volume of the second event was significantly larger than the first one. This scenario seems to occur due to a kind of switch of the event magnitude, both in terms of the total solid volume $(V)$ and normalized solid volume $\left(V / I_{30}\right.$ TRIGG $\mathrm{I}_{30 \text { тRा }}$...., which obliterated the memory effect of the previous DF/DFD with much larger volumes of a DF event (and not a DFD; see also Fig. 4). Therefore, these two event pairs partially confirm the behavior described by Brayshaw and Hassan (2009), in which the instability caused by the antecedent event could leave the catchment in a more unstable state, but the final response, which is a greater or larger volume than the expectation, remains uncertain. The relict presence of loose debris in the source area and in the transport channel could have facilitated the sudden triggering of a DF/DFD of a subsequent DF/DFD event. event. Such a scenario also explains why, in some cases, the triggering rainfall events had a low intensity and a low total precipitation (Table 1). This increment of basin susceptibility to DF/DFD events has also been described by Coe et al. (2008) for the Chalk Cliffs study area. In fact, they found that the period between two 
$\mathrm{DF} / \mathrm{DFD}$ events can be very short and a DF/DFD event is triggered, in some cases, by rainfall events that have a low return period. Conversely, Berger et al. (2011) found that in the Illgraben catchment, the channel segments recently incised by DF events have a lower probability of triggering another event in a short time, since right after the first event, the area is relatively more stable.

In short, there is no definitive answer for the effect of subsequent torrential flows, but it may be concluded that, given a catchment with a high sediment supply, the second event response, when the triggering threshold is exceeded, appears contradictory. It generally tends to be lower or of the same order but is likely higher when a DF follows a DFD event. The difference in normalized sediment volumes $\left(V / I_{30}\right.$ TRIGG , Fig. 4$)$ seems to provide a kind of DF/DFD discrimination (a value of $150 \mathrm{~m}^{3} \mathrm{~mm}^{-1} \mathrm{~h}^{-1}$ ) only for close events, but it is partially conditioned by the small volumes of DFD events necessitating further data for its verification.

\section{Conclusions}

In this study, we analyzed a small catchment located in the Spanish Pyrenees and characterized by unlimited sediment supply. We tried to understand the correlation between the sediment accumulation during the recharge periods between consecutive events and the intermediate rainfalls during the same periods. We wanted to know if the mobilized volume was influenced by the intermediate rainfalls and/or by the triggering rainfalls. To reach this objective, we used some significant rainfall parameters (i.e., $I_{\Delta t \max }$ and $\mathrm{EI}_{\Delta t \max }$ ), and the results brought us to the following conclusions:

- The volume of the DF/DFD events was not related to the intermediate rainfall characteristics of the recharge period; namely, similar rainfall events were able to trigger DF/DFD events with very different magnitudes. In short, it seems inappropriate to link the volume of the DF/DFD events to the return periods of the triggering rainfall.

- The analyzed rainfall parameters variables $\left(I_{\Delta t \text { TRIG }}, \mathrm{EI}_{\Delta t \mathrm{TRIG}}, E_{\mathrm{k}}\right)$ were highly capable of discriminating between triggering and non-triggering DF/DFD events.

- Many DF/DFD events were triggered soon after the previous ones, showing that the susceptibility to DF/DFD triggering tends to increase. The amount of sediment volume of the second event was difficult to predict, and the process-type (DF or DFD) dominates the released volume and highlights a normalized volume $\left(V / I_{30}\right.$ TRIGG $)$ for close events of about $150 \mathrm{~m}^{3} \mathrm{~mm}^{-1} \mathrm{~h}^{-1}$, separating DFD from DF events. 
- The calibration of a threshold relationship between $I_{30 \text { max }}$ and $E_{\mathrm{k}}$ results is an excellent strategy to discriminate between triggering and non-triggering rainfall events. This type of calculation might be a good alternative to the classic intensity-duration analysis and merits further confirmation, particularly in those instrument-equipped DF/DFD basins where rain gauges and triggering areas are proximate and early-warning systems are operating.

\section{Acknowledgments}

We thank the "Fondazione Ing. Aldo Gini" which supported the PhD student Roberta Pastorello with a scholarship to spend 6 months during 2016 at BarcelonaTech (UPC), Spain.

Funding information

Monitoring at Rebaixader is funded by the Ministry of Economy and Competitiveness of Spain (SMuCPhy project, BIA 2015-67500-R).

\section{Electronic supplementary material}

\section{ESM 1}

(DOCX $19 \mathrm{~kb})$

\section{References}

Abancó C, Hürlimann M, Moya J, Berenguer M (2016) Critical rainfall conditions for the initiation of torrential flows. Results from the Rebaixader catchment (Central Pyrenees). J Hydrol 541:218-229. https://doi.org/10.1016/j.jhydrol.2016.01.019

Bacchini M, Zannoni A (2003) Relations between rainfall and triggering of debris-flow: case study of Cancia (Dolomites, Northeastern Italy). Nat Hazards Earth Syst Sci 3:71-79. https://doi.org/10.5194/nhess-3-71-2003

Badoux A, Graf C, Rhyner J, Kuntner R, McArdell BW (2009) A debris-flow alarm system for the Alpine Illgraben catchment: design and performance. Nat Hazards 49:517-539. https://doi.org/10.1007/s11069-008-9303-x

Beguería S (2006) Validation and evaluation of predictive models in hazard assessment and risk management. Nat Hazards 37:315-329. 
https://doi.org/10.1007/s11069-005-5182-6

Bel C, Liébault F, Navratil O, Eckert N, Bellot H, Fontaine F, Laigle D (2017) Rainfall control of debris-flow triggering in the Réal Torrent, Southern French Prealps. Geomorphology 291:17-32. https://doi.org/10.1016/j.geomorph.2016.04.004

Berger C, McArdell BW, Schlunegger F (2011) Sediment transfer patterns at the Illgraben catchment, Switzerland: implications for the time scales of debris flow activities. Geomorphology 125:421-432.

https://doi.org/10.1016/j.geomorph.2010.10.019

Berti M, Simoni A (2005) Experimental evidences and numerical modelling of debris flow initiated by channel runoff. Landslides 2:171-182. https://doi.org/10.1007/s10346-005-0062-4

Borga M, Stoffel M, Marchi L, Marra F, Jakob M (2014) Hydrogeomorphic response to extreme rainfall in headwater systems: flash floods and debris flows. J Hydrol 518:194-205. https://doi.org/10.1016/j.jhydrol.2014.05.022

Bovis MJ, Jakob M (1999) The role of debris supply conditions in predicting debris flow activity. Earth Surf Process Landforms 24:1039-1054. https://doi.org/10.1002/(SICI)1096-9837(199910)24:11<1039::AIDESP29>3.0.CO;2-U

Brayshaw D, Hassan MA (2009) Debris flow initiation and sediment recharge in gullies. Geomorphology 109:122-131. https://doi.org/10.1016/j.geomorph.2009.02.021

Cannon SH, Bigio ER, Mine E (2001) A process for fire-related debris flow initiation, Cerro Grande fire, New Mexico. Hydrol Process 15:3011-3023. https://doi.org/10.1002/hyp.388

Carollo FG, Ferro V, Serio MA (2016) Estimating rainfall erosivity by aggregated drop size distributions. Hydrol Process 30:2119-2128. https://doi.org/10.1002/hyp.10776

Carrara A, Crosta G, Frattini P (2008) Comparing models of debris-flow susceptibility in the Alpine environment. Geomorphology 94:353-378. https://doi.org/10.1016/j.geomorph.2006.10.033 
Cavalli M, Trevisani S, Comiti F, Marchi L (2013) Geomorphometric assessment of spatial sediment connectivity in small Alpine catchments. Geomorphology 188:31-41. https://doi.org/10.1016/j.geomorph.2012.05.007

Coe JA, Kinner DA, Godt JW (2008) Initiation conditions for debris flows generated by runoff at Chalk Cliffs, Central Colorado. Geomorphology 96:270-297. https://doi.org/10.1016/j.geomorph.2007.03.017

Comiti F, Marchi L, Macconi P, Arattano M, Bertoldi G, Borga M, Brardinoni F, Cavalli M, D'Agostino V, Penna D, Theule J (2014) A new monitoring station for debris flows in the European Alps: first observations in the Gadria basin. Nat Hazards 73:1175-1198. https://doi.org/10.1007/s11069-014-1088-5

Corominas J, Moya J (2008) A review of assessing landslide frequency for hazard zoning purposes. Eng Geol 102:193-213. https://doi.org/10.1016/j.enggeo.2008.03.018

Crosta GB, Frattini P (2003) Distributed modelling of shallow landslides triggered by intense rainfall. Nat Hazards Earth Syst Sci 3:81-93

Crosta GB, Frattini P (2008) Rainfall-induced landslides and debris flows. Hydrol Process 22:473-477. https://doi.org/10.1002/hyp.6885

D'Agostino V, Bertoldi G (2014) On the assessment of the management priority of sediment source areas in a debris-flow catchment. Earth Surf Process Landforms 39:656-668. https://doi.org/10.1002/esp.3518

Deganutti AM, Marchi L, Arattano M (2000) Rainfall and debris-flow occurrence in the Moscardo basin (Italian Alps). In: Wieczorek GF, Naeser ND (eds) Debris flow hazards mitigation: mechanics, prediction, and assessment; Proceedings of the 2nd international DFHM conference. Taipei, Taiwan, pp 67-72

Destro E, Marra F, Nikolopoulos EI, Zoccatelli D, Creutin JD, Borga M (2017) Spatial estimation of debris flows-triggering rainfall and its dependence on rainfall return period. Geomorphology 278:269-279. https://doi.org/10.1016/j.geomorph.2016.11.019

Di Stefano C, Ferro V, Pampalone V, Sanzone F (2013) Field investigation of rill and ephemeral gully erosion in the Sparacia experimental area, South Italy. Catena 101:226-234. https://doi.org/10.1016/j.catena.2012.10.012 
Dong J-J, Lee C-T, Tung Y-H, Liu CN, Lin KP, Lee JF (2009) The role of the sediment budget in understanding debris flow susceptibility. Earth Surf Process Landforms 34:1612-1624. https://doi.org/10.1002/esp.1850

Dowling CA, Santi PM (2014) Debris flows and their toll on human life: a global analysis of debris-flow fatalities from 1950 to 2011. Nat Hazards 71:203-227. https://doi.org/10.1007/s11069-013-0907-4

Floris M, D'Alpaos A, Squarzoni C et al (2010) Recent changes in rainfall characteristics and their influence on thresholds for debris flow triggering in the dolomitic area of Cortina d'Ampezzo, north-eastern Italian Alps. Nat Hazards Earth Syst Sci 10:571-580. https://doi.org/10.5194/nhess-10-5712010

Gartner JE, Cannon SH, Santi PM, Dewolfe VG (2008) Empirical models to predict the volumes of debris flows generated by recently burned basins in the western U.S. Geomorphology 96:339-354. https://doi.org/10.1016/j.geomorph.2007.02.033

Gregoretti C, Dalla Fontana G (2008) The triggering of debris flow due to channel-bed failure in some Alpine headwater basins of the Dolomites: analyses of critical runoff. Hydrol Process 22:2248-2263. https://doi.org/10.1002/hyp.6821

Guthrie RH (2002) The effects of logging on frequency and distribution of landslides in three watersheds on Vancouver Island, British Columbia. Geomorphology 43:273-292. https://doi.org/10.1016/S0169-555X(01)001386

Hungr O, Leroueil S, Picarelli L (2013) The Varnes classification of landslide types, an update. Landslides 11:167-194. https://doi.org/10.1007/s10346-013$0436-\mathrm{y}$

Hürlimann M, Rickenmann D, Graf C (2003) Field and monitoring data of debris-flow events in the Swiss Alps. Can Geotech J 40:161-175. https://doi.org/10.1139/t02-087

Hürlimann M, Abancó C, Moya J (2012) Rockfalls detached from a lateral moraine during spring season. 2010 and 2011 events observed at the Rebaixader debris-flow monitoring site (Central Pyrenees, Spain). Landslides 9:385-393. https://doi.org/10.1007/s10346-011-0314-4 
Hürlimann M, Abancó C, Moya J, Vilajosana I (2014) Results and experiences gathered at the Rebaixader debris-flow monitoring site, Central Pyrenees, Spain. Landslides 11:939-953. https://doi.org/10.1007/s10346-0130452-y

Hürlimann M, Abancó C, Moya J (2016) Debris-flow monitoring for the setup of a warning and alarm system-experiences from the Pyrenees. Int J Eros Control Eng 9:107-113. https://doi.org/10.13101/ijece.9.107

Imaizumi F, Sidle RC, Tsuchiya S, Ohsaka O (2006) Hydrogeomorphic processes in a steep debris flow initiation zone. Geophys Res Lett 33:n/a-n/a. https://doi.org/10.1029/2006GL026250

Jakob M (2005) A size classification for debris flows. Eng Geol 79:151-161. https://doi.org/10.1016/j.enggeo.2005.01.006

Jakob M, Bovis M, Oden M (2005) The significance of channel recharge rates for estimating debris-flow magnitude and frequency. Earth Surf Process Landforms 30:755-766. https://doi.org/10.1002/esp.1188

Kappes MS, Malet J-P, Remaître A, Horton P, Jaboyedoff M, Bell R (2011) Assessment of debris-flow susceptibility at medium-scale in the Barcelonnette Basin, France. Nat Hazards Earth Syst Sci 11:627-641. https://doi.org/10.5194/nhess-11-627-2011

Kappes MS, Gruber K, Frigerio S, Bell R, Keiler M, Glade T (2012) The MultiRISK platform: the technical concept and application of a regional-scale multihazard exposure analysis tool. Geomorphology 151-152:139-155. https://doi.org/10.1016/j.geomorph.2012.01.024

Kinnell PIA (2010) Event soil loss, runoff and the universal soil loss equation family of models: a review. J Hydrol 385:384-397.

https://doi.org/10.1016/j.jhydrol.2010.01.024

Marchi L, D'Agostino V (2004) Estimation of debris-flow magnitude in the eastern Italian Alps. Earth Surf Process Landforms 29:207-220. https://doi.org/10.1002/esp.1027

McArdell BW, Bartelt P, Kowalski J (2007) Field observations of basal forces and fluid pore pressure in a debris flow. Geophys Res Lett 34:2-5. https://doi.org/10.1029/2006GL029183 
McCoy SW, Kean JW, Coe JA et al (2010) Evolution of a natural debris flow: in situ measurements of flow dynamics, video imagery, and terrestrial laser scanning. Geology 38:735-738. https://doi.org/10.1130/G30928.1

Munoz JA (1992) Evolution of a continental collision belt: ECORS-Pyrenees crustal balanced cross-section. In: Thrust tectonics, pp 235-246. https://doi.org/10.1007/978-94-011-3066-0_21

Panagos P, Meusburger K, Van Liedekerke M et al (2014) Assessing soil erosion in Europe based on data collected through a European network. Soil Sci Plant Nutr 60:15-29. https://doi.org/10.1080/00380768.2013.835701

Panagos P, Ballabio C, Borrelli P, Meusburger K, Klik A, Rousseva S, Tadić MP, Michaelides S, Hrabalíková M, Olsen P, Aalto J, Lakatos M, Rymszewicz A, Dumitrescu A, Beguería S, Alewell C (2015) Rainfall erosivity in Europe. Sci Total Environ 511:801-814. https://doi.org/10.1016/j.scitotenv.2015.01.008

Regues D, Gallart F (1999) Physical weathering as a key process of badland dynamics at Vallcebre, Eastern Pyrenees. In: Mathys N (ed) Les bassins versants expérimentaux de Draix laboratoire d'étude de l'érosion en montagne - actes du séminaire, Draix Le Brusquet Digne, 22-24 octobre 1997, Cemagref E. pp 173-185

Reid, M.E. et al., 2012. Real-Time Monitoring of Landslides, U.S. Geological Survey Fact Sheet 2012-3008 (4 pp.)

Rickenmann D, Zimmermann M (1993) The 1987 debris flows in Switzerland: documentation and analysis. Geomorphology 8:175-189. https://doi.org/10.1016/0169-555X(93)90036-2

Theule JI, Liébault F, Loye a et al (2012) Sediment budget monitoring of debris-flow and bedload transport in the Manival Torrent, SE France. Nat Hazards Earth Syst Sci 12:731-749. https://doi.org/10.5194/nhess-12-7312012

Van Dijk AIJM, Bruijnzeel LA, Rosewell CJ (2002) Rainfall intensity-kinetic energy relationships: a critical literature appraisal. J Hydrol 261:1-23. https://doi.org/10.1016/S0022-1694(02)00020-3 
Wieczorek GF, Glade T (2005) Climatic factors influencing occurrence of debris flows. In: Jakob M, Hungr O (eds) Debris-flow hazards and related phenomena. Springer, Berlin, pp 325-326

Wischmeier W, Smith DD (1978) Predicting rainfall erosion losses-A guide to conservation planning. Agriculture Handbook 537:58.

Xie Y, qing YS, yuan LB et al (2016) Models for estimating daily rainfall erosivity in China. J Hydrol 535:547-558.

https://doi.org/10.1016/j.jhydrol.2016.02.020

M. Hrachowitz, M. Weiler, (2011) Uncertainty of Precipitation Estimates Caused by Sparse Gauging Networks in a Small, Mountainous Watershed. Journal of Hydrologic Engineering 16 (5):460-471

R Development Core Team (2005) R: A language and environment for statistical computing. Vienna, Austria 